\title{
Peranan Kedisiplinan Kerja Dalam Meningkatkan Produktivitas Kerja Pegawai Di Pustu Desa Botolakha Kecamatan Tuhemberua Kabupaten Nias Utara
}

\author{
Maria Magdalena Bate'e \\ Sekolah Tinggi Ilmu Ekonomi Pembangunan Nasional \\ maria.batee82@gmail.com
}

\begin{abstract}
Abstrak
Disiplin kerja merupakan faktor yang dituntut oleh suatu organisasi ataupun dalam instansi pemerintahan. Sebagai ketentuan dan konsekuensi seseorang dalam bekerja, disiplin kerja sangat mempengaruhi produktivitas kerja pegawai. Adanya tindakan disiplin dari setiap orang atau setiap pegawai pada instansi pemerintah dapat menjadi kekuatan positif bagi organisasi pemerintahan manakala tindakan itu diterapkan secara bertanggungjawab dan adil serta dapat menumbuhkan atau mempertahankan rasa hormat dan saling percaya diantara atasan dengan bawahanya dan membantu pegawai menjadi lebih produktif, dengan demikian dapat menumbuhkan Produktivitas kerja pegawai. Adapun tujuan penelitian ini adalah untuk mengetahui bagaimana kedisiplinan kerja pegawai dan produktivitas kerja pegawai di Pustu Desa Botolakha Kecamatan Tuhemberua Kabupaten Nias Utara, sementara manfaat dari penelitian ini dapat menjadi bahan masukan dalam membuat kebijakan untuk meningkatkan kedisiplinan di Pustu Desa Botolakha Kecamatan Tuhemberua Kabupaten Nias Utara. Jenis penelitian yang dilakukan dalam penelitian ini adalah jenis penelitian kualitatif. Yang menjadi populasi dalam penelitian ini adalah seluruh pegawai Pustu Desa Botolakha berjumlah 10 orang dengan pengambilan sampel secara insidental. Teknik pengumpulan data dalam penelitian ini adalah melakukan pengamatan dan wawancara. Hasil dari penelitian ini adalah (1) kedisiplinan di Pustu Desa Botolakha Kabupaten Nias Utara terlaksana dengan baik, (2) adanya komunikasi yang baik antar pegawai yang satu dengan yang lain di Pustu Desa Botolakha Kabupaten Nias Utara, (3) adanya keterikatan yang tidak dapat dipisahkan antara kedisiplinan dan produktivitas kerja pegawai, (4) kedisiplinan pegawai terlaksana dengan baik, dan (5) pegawai Pustu Desa mencirikan pegawai yang produktivitas.
\end{abstract}

Kata Kunci Kedisiplinan dan Produktivitas Kerja Pegawai

\section{PENDAHULUAN}

Pekerja atau pegawai adalah makhluk sosial yang menjadi kekayaan bagi setiap instansi pemerintahan maupun perusahaan. Sebagai manusia, pegawai memiliki pikiran dan perasaan yang dapat berpengaruh pada pekerjaannya, namun disamping itu memiliki keterbatasan dalam melakukan kegiatan operasionalnya. Tujuan seseorang untuk bekerja utamanya disebabkan oleh adanya kebutuhan hidup yang harus dipenuhi, dan pegawai akan bekerja sesuai dengan kenyataan, namun situasi sebenarnya yang sering kali terjadi adalah kebutuhan pegawai tidak dapat terpenuhi. Hal ini timbul bisa karena pegawai selalu saja tidak merasa puas dengan apa yang diterimanya dan juga karena imbalan yang diterima juga tidak sesuai. Dengan situasi yang seperti ini berpengaruh pada kedisiplinan kerja. Disiplin kerja merupakan faktor yang dituntut oleh suatu 
organisasi ataupun dalam instansi pemerintahan. Sebagai ketentuan dan konsekuensi seseorang dalam bekerja, disiplin kerja sangat mempengaruhi produktivitas kerja pegawai. Disiplin terhadap tugas dan tanggung jawab merupakan kewajiban bagi setiap pegawai sesuai dengan hak yang diterimanya, karena hal itu perlu adanya keseimbangan antara hak dan kewajiban sehingga disiplin kerja akan tercapai.

Adanya tindakan disiplin dari setiap orang atau setiap pegawai pada instansi pemerintah dapat menjadi kekuatan positif bagi organisasi pemerintahan manakala tindakan itu diterapkan secara bertanggungjawab dan adil serta dapat menumbuhkan atau mempertahankan rasa hormat dan saling percaya diantara atasan dengan bawahanya dan membantu pegawai menjadi lebih produktif, dengan demikian dapat menumbuhkan Produktivitas kerja pegawai.

Produktivitas merupakan hasil dari pencapaian kerja dalam kurun waktu tertentu. Produktivitas sangat menentukan prestasi organisasi karena Produktivitas merupakan hal yang sangat penting untuk menjaga agar kegiatan administrasi dapat berlangsung dengan baik. Produktivitas individu dapat dinilai dari apa yang dilakukan oleh individu tersebut dalam kerjanya. Dengan kata lain Produktivitas individu adalah bagaimana seseorang melaksanakan pekerjaannya atas unjuk kerja (job performance). Produktivitas yang dihasilkan suatu organisasi tidak akan terlepas dari efektivitas yang dilaksanakan organisasi tersebut.

Dari hasil penelitian terdahulu yang dilakukan di PT. Perkebunan Nusantara IV Kebon Tobasari menyatakan bahwa kedisiplinan kerja memberikan pengaruh yang positif dalam meningkatkan produktivitas kerja karyawan (Silalahi, 2017). Demikian pula penelitian yang dilakukan oleh Hartono di PT Festino bahwa terdapat pengaruh kedisiplinan kerja dalam meningkatkan produktivitas kerja karyawan pada PT Festino Jakarta Barat (Yudapratama, 2017). Sedangkan penelitian lain menyatakan bahwa produktivitas kerja karyawan akan semakin meningkat secara positif dipengaruhi oleh motivasi kerja karyawan yang baik dan kedisiplinan kerja yang tinggi (Trihudiyatmanto, 2017). Berdasarkan ketiga penelitian ini dapat disimpulkan bahwa kedisiplinan sangat penting dan mendukung meningkatnya produktivitas kerja pegawai dalam setiap organisasi.

Dalam penelitian yang dilakukan saat ini, kondisi para pegawai yang ada di Puskesmas Pembantu (Pustu) Desa Sisarahili Kecamatan Mandrehe Kabupaten Nias Barat masih ditemui pegawai yang menunjukkan perilaku yang kurang disiplin seperti tidak tertib dalam bekerja, kurang patuh pada perintah atasan, menunda pekerjaan, dan melaksanakan tugas tidak sesuai dengan tugas pokok dan fungsinya, dan kemudian ada juga pegawai yang secara kolektif memberanikan diri untuk mengambil alih dari setiap pekerjaan pegawai yang lain. Melihat kondisi tersebut dipastikan produktivitas pegawainya menurun. Seperti telah dikemukakan di atas bahwa kedisiplinan berperan dalam meningkatkan produktivitas pegawai. Oleh karena itu setiap instansi hendaknya memperhatikan kondisi para pegawainya.

Dari fenomena di atas, maka penelitian ini memiliki tujuan yaitu untuk mengetahui bagaimana disiplin kerja pegawai dan juga untuk mengetahui tingkat produktivitas kerja pegawai di Pustu Desa Botolakha Kecamatan Tuhemberua Kabupaten Nias Utara.

\section{LANDASAN TEORI}

\section{Pengertian Kedisiplinan}

Adapun beberapa pendapat para ahli tentang definisi kedisiplinan antara lain: Disiplin berasal dari bahasa latin discipline yang berarti latihan atau pendidikan kesopanan dan kerohanian serta pengembangan tabiat. Ada juga yang mengatakan berasal dari kata disciple yang berarti pengikut setia, penganut terhadap paham seorang guru, dan ajaran atasi aliran seni (Sulfemi, 2018). Selain itu menurut Bugis Suraji, disiplin kerja merupakan suatu sikap dan perilaku yang berniat untuk mentaati segala peraturan organisasi yang didasarkan atas kesadaran diri untuk menyesuaikan dengan peraturan organisasi (Bugis, 2018). Pendapat lain oleh Rivai dan Sagala 
menyatakan bahwa disiplin kerja adalah suatu alat yang digunakan para manajer untuk berkomunikasi dengan karyawan agar mereka bersedia untuk mengubah suatu perilaku dan untuk meningkatkan kesadaran juga kesediaan seseorang agar menaaati semua peraturan dan norma sosial yang berlaku di suatu perusahaan (Diah Indriani Suwondo, 2015) . Dan sejalan dengan Rivai dan Sagala. Bagi Sintaasih dan Wiratama, disiplin kerja adalah merupakan tindakan manajemen untuk mendorong kesadaran dan kesediaan para anggotanya untuk mentaati semua peraturan yang telah ditentukan oleh organisasi atau perusahaan dan norma-norma sosial yang berlaku secara sukarela (Mauliya Siti Aisyah, 2019).

Kedisiplinan sering menjadi suatu syarat untuk tercapainya sesuatu sehingga dalam setiap peraturan di instansi apapun peraturan mengenai kedisiplinan pasti selalu ada. Hal ini disebabkan karena pentingnya peranan kedisiplinan dalam mencapai standar-standar organisasi. Seperti yang diungkapkan oleh Hasibuan bahwa kedisiplinan adalah kesadaran dan kesediaan seseorang mentaati semua peraturan perusahaan dan norma-norma sosial yang berlaku. Kesadaran adalah sikap seseorang yang secara sukarela menaati semua peraturan dan sadar akan tugas dan tanggung jawabnya. Jadi, dia akan mematuhi atau mengerjakan semua tugasnya dengan baik, bukan atas paksaan (Harahap, 2016).

Memperhatikan pendapat-pendapat di atas dapat disimpulkan bahwa disiplin menghendaki ditaatinya peraturan-peraturan suatu organisasi atau institusi oleh semua pegawai, dengan adanya kedisiplinan yang baik maka akan terciptanya rasa tanggungjawab yang dimiliki oleh setiap pegawai dalam hal melaksanakan tugas dan kewajibannya serta dapat dicapai apa yang menjadi tujuan suatu organisasi atau institusi.

\section{Pentingnya Disiplin}

Mengingat pentingnya peranan pegawai dalam suatu perusahaan maka perlu menanamkan kesadaran kedisiplinan pribadi pada pegawai, untuk mencegah penyimpangan atau pelanggaran dalam menjalankan aktivitas perusahaan, oleh karena itu tindakan-tindakan disiplin tidak hanya berpengaruh terhadap mental pegawai saja tetapi juga berpengaruh terhadap Produktivitas kerja. Kedisiplinan adalah fungsi operatif keenam dari manajemen sumber daya manusia. Kedisipilinan merupakan fungsi operatif manajemen sumber daya manusia yang terpenting karena semakin baik disiplin pegawai semakin tinggi prestasi kerja yang dapat dicapainya. Tanpa disiplin pegawai yang baik sulit bagi organisasi instansi pemerintahan untuk mencapai hasil yang optimal. Disiplin yang baik mencerminkan besarnya tanggungjawab seseorang terhadap tugas-tugas yang diberikan kepadanya. Hal ini mendorong gairah kerja, semangat kerja, dan terwujudnya tujuan instansi, pegawai, dan mayarakat. Oleh karena itu setiap pimpinan selalu berusaha agar bawahanya mempunyai disiplin yang baik.

Dalam menerapkan kedisiplinan diperlukan peraturan dan hukuman, peraturan sangat diperlukan untuk memberikan bimbingan dan penyuluhan bagi tenaga kerja dalam menciptakan tata tertib yang baik dalam instansi pemerintah. Dengan tata tertib yang baik, semangat kerja, moral kerja, efisiensi dan efektifitas kerja tenaga kerja akan meningkat. Hal ini akan mendukung tercapainya tujuan instansi, pegawai, dan masyarakat. Jelasnya instansi sulit mencapai tujuan dari instansinya, jika tenaga kerja tidak memenuhi peraturan-peraturan perusahaan tersebut. Kedisiplinan suatu dikatakan baik jika sebagian besar tenaga kerjanya menaati peraturan yang ada.

Hukum diperlukan dalam meningkatkan kedisiplinan dan mendidik pegawai supaya menaati semua peraturan instansi organisasi pemerintahan. Pemberian hukuman harus adil dan tegas terhadap semua pegawai. Peraturan tanpa diikuti pemberian hukuman yang tegas bagi pelanggarnya bukan menjadi alat pendidik bagi pegawai. 
Kedisiplinan harus ditegakkan dalam suatu instansi pemerintahan. Tanpa dukungan disiplin tenaga kerja yang baik, sulit bagi instansi untuk mewujudkan tujuannya. Jadi, kedisiplinan adalah kunci keberhasilan suatu perusahaan dalam mencapai tujuanya.

\section{Jenis-Jenis Disiplin Kerja}

Newstrom dalam Asmiarsih (Asmiarsih, 2014), menyatakan bahwa disiplin kerja mempunyai 3 (tiga) macam bentuk, yaitu :

1. Disiplin Preventif

Disiplin preventif adalah tindakan sumber daya manusia agar terdorong untuk menaati standar atau peraturan.Tujuan pokoknya adalah mendorong sumber daya manusia agar memiliki disiplin pribadi yang tinggi, agar peran kepemimpinan tidak terlalu berat dengan pengawasan atau pemaksaan, yang dapat mematikan prakarsa dan kreativitas serta partisipasi sumber daya manusia.

2. Disiplin Korektif

Disiplin korektif adalah tindakan dilakukan setelah terjadi pelanggaran standar atau peraturan, tindakan tersebut dimaksud untuk mencegah timbulnya pelanggaran lebih lanjut.Tindakan itu biasanya berupa hukuman tertentu yang biasa disebut sebagai tindakan disipliner, antara lain berupa peringatan, skors, pemecatan.

3. Disiplin Progresif

Disiplin progresif adalah tindakan disipliner berulang kali berupa hukuman yang makin berat, dengan maksud agar pihak pelanggar bisa memperbaiki diri sebelum hukuman berat dijatuhkan.

\section{Prinsip-Prinsip Disiplin Kerja}

Menurut Heidrajchman dalam Ony (Noviantari, 2017) untuk mengkondisikan karyawan perusahaan agar bisa melaksanakan tindakan disiplin maka terdapat beberapa prinsip pendisiplinan diantaranya adalah sebagai berikut:

1. Pendisiplinan secara pribadi

Pendisiplinan ini dilakukan dengan menghindari menegur kesalahan dihadapan orang banyak karena apabila hal tersebut dilakukan, pegawai akan malu dan tidak menutup kemungkinan pegawai sakit hati yang dapat menimbulkan rasa dendam dan dapat melakukan tindakan balas dendam yang akhirnya merugikan perusahaan.

2. Pendisiplinan harus bersifat membangun

Pendisiplinan ini dilakukan dengan menghindari menegur kesalahan didepan orang banyak agar karyawan yang bersangkutan tidak merasa malu dan sakit hati.

3. Keadilan dalam pendisiplinan Pendisiplinan dilakukan secara adil tanpa pilih kasih siapapun yan telah melakukan kesalahan harus mendapatkan tindakan pendisiplinan

\section{Indikator-Indikator Kedisiplinan}

Menurut Hasibuan dalam Pratiwi, ada beberapa indikator yang mempengaruhi kedisiplinan kerja pegawai dalam suatu organisasi (Pratiwi, 2018) diantaranya:

1. Tujuan dan kemampuan.

Tujuan dan kemampuan ikut mempengaruhi tingkat kedisiplinan karyawan. Tujuan yang akan dicapai harus jelas dan ditetapkan secara ideal. Hal ini berarti bahwa tujuan atau yang dibebankan kepada karyawan harus sesuai dengan kemampuan karyawan yang bersangkutan, agar karyawan dapat bekerja sungguh-sungguh dan disiplin dalam mengerjakannya.

2. Teladan kepemimpinan 
Teladan pimpinan sangat berperan dalam menentukan kedisiplinan karyawan karena pimpinan dijadikan teladan dan panutan. Para pimpinan harus memberikan contoh yang baik karena dengan pimpinan yang baik maka kedisiplinan karyawan pun akan meningkat.

3. Balas jasa

Balas jasa berupa gaji dan kesejahteraan ikut mempengaruhi kedisiplinan karyawan karena balas jasa akan memberikan kepuasan pada karyawan. Dengan adanya balas jasa yang cukup, hal itu akan memberikan kepuasan bagi karyawan, sehingga apabila kepuasan karyawan tercapai maka kedisiplinan akan terwujud dalam perusahaan.

4. Keadilan

Keadilan yang dijadikan dasar kebijakan dalam pemberian balas jasa atau hukuman akan merangsang terciptanya kedisiplinan karyawan yang baik. Keadilan ikut mendorong terwujudnya kedisiplinan karyawan karena sifat manusia yang selalu merasa dirinya penting dan meminta diberlakukan secara adil dengan manusia yang lain.

5. Pengawasan melekat

Pengawasan melekat ini yaitu atasan harus aktif dan turun langsung mengawasi perilaku yang dilakukan karyawannya. Hal ini berarti atasan harus selalu hadir di tempat kerja agar dapat mengawasi dan memberikan petunjuk kepada karyawan, apabila ada karyawannya yang mengalami kesulitan. Pengawasan melekat merupakan tindakan yang paling efektif dalam mewujudkan kedisiplinan kerja para karyawan dalam perusahaan.

6. Sanksi hukum

Sanksi hukuman berperan penting dalam memelihara kedisiplinan karyawan. Dengan adanya sanksi hukuman, kemungkinan besar karyawan tidak akan melanggar peraturan- peraturan yang berlaku. Berat atau ringan sanksi yang diberikan dapat mengubah perilaku para karyawan agar tidak mengulangi kesalahan sebelumnya.

7. Ketegasan

Ketegasan pimpinan dalam melakukan tindakan akan mempengaruhi kedisiplinan karyawan. Pimpinan harus berani dan tegas, bertindak untuk memberikan hukuman kepada setiap karyawan yang indisipliner sesuai dengan sanksi hukuman yang telah ditentukan. Pimpinan yang tegas dalam menerapkan hukuman akan disegani dan diakui kepemimpinannya.

8. Hubungan Kemanusiaan

Hubungan kemanusian yang harmonis di antara pegawai ikut menciptakan kedisiplinan yang baik di suatu perusahaan. Manajer atau pimpinan harus mewujudkan suasana hubungan kemanusiaan yang serasi, vertical maupun horizontal. Hubungan vertical disini yaitu antara karyawan dengan pimpinan. Sedangkan hubungan horizontal yaitu antara sesama karyawan. Jadi, terciptanya hubungan kemanusian yang serasi akan mewujudkan lingkungan dan suasana kerja yang nyaman.

\section{Pengertian Produktivitas Kerja}

Produktivitas mengandung pengertian filosofis, definisi kerja, dan teknis operasional. Secara filosofis produktivitas mengandung pandangan hidup dan sikap mental yang selalu berusaha untuk meningkatkan mutu kehidupan. Keadaan hari ini harus lebih baik dari kemarin dan mutu kehidupan besok harus lebih baik dari hari ini. Pandangan hidup dan sikap mental yang demikian akan mendorong manusia untuk tidak cepat merasa puas dan akan terus meningkatkan kemampuan kerjanya.

Produktivitas kerja sebenarnya mencakup tentang suatu sikap mental yang selalu mempunyai pandangan kehidupan mengenai pelaksanaan produksi didalam suatu perusahaan dimana dalam memproduksi untuk hari ini diharapkan lebih baik dari hari kemarin begitu juga 
sistem kerjanya. Seseorang selalu mencari perbaikan-perbaikan dengan berfikir dinamis, kreatif serta terbuka.

Menurut Hasibuan dalam T Sembiring, produktivitas adalah perbandingan antara hasil dengan masukan, peningkatan produktivitas hanya dimungkinkan oleh adanya peningkatan efesiensi (waktu, bahan dan tenaga) serta sistem kerja, teknik produksi dan adanya peningkatan keterampilan dari tenaga kerja (Sembiring, 2016)

Dewan Produktivitas Indonesia telah merumuskan defenisi produktivitas secara lengkap yaitu sebagai berikut menurut Umar Husein (Sembiring, 2016)

1. Produktivitas pada dasarnya merupakan suatu sikap mental yang selalu mempunyai pandangan bahwa mutu kehidupan hari ini lebih baik dari kemarin dan hari esok lebih baik dari hari ini.

2. Secara umum Produktivitas mengandung pengertian perbandingan antara hasil yang dicapai (output) dengan keseluruhan sumber daya yang digunakan (input).

3. Produktivitas mempunyai dua dimensi yaitu efektivitas yang mengarah pada pencapaian unjuk kerja yang maksimal. Yang ke dua efesiensi yang berkaitan dengan upaya membandingkan input dengan realisasi penggunaannya atau bagaimana pekerjaan tersebut dilaksanakan.

Menurut Sinungan dalam Hendra (Hendra Praja, 2017), membagi pengertian produktivitas dalam tiga hal, yaitu:

1. Produktivitas adalah rasio dari apa yang dihasilkan (output) terhadap keseluruhan peralatan produksi yang dipergunakan (input).

2. Produktivitas pada dasarnya adalah sikap mental yang mempunyai pandangan bahwa mutu kehidupan hari ini lebih baik dari pada kemarin dan hari esok lebih baik hari ini.

3. Produktivitas merupakan interaksi terpadu secara resmi dari tiga faktor yang esensial yaitu invertasi termasuk penggunaan pengetahuan dan teknologi serta riset manajemen dan tenaga kerja.

Dari beberapa pengertian-pengertian tersebut dapat disimpulkan bahwa Produktivitas mengandung pengertian:

1. Sikap mental yang selalu mempunyai pandangan bahwa mutu kehidupan hari ini harus lebih baik dari hari kemarin dan hari esok lebih baik dari hari ini.

2. Perbandingan antara hasil yang dicapai dengan keseluruhan sumber daya yang dipergunakan.

3. Produksi dan Produktivitas merupakan pengertian yang berbeda. Peningkatan produksi menunjukkan pertumbuhan jumlah hasil yang dicapai sedangkan peningkatan Produktivitas mengandung pengertian pertambahan hasil dan perbaikan cara pencapaian hasil tersebut. Peningkatan Produktivitas dapat dilihat dengan membandingkan input dan output.

Kesimpulan dari uraian di atas bahwa Produktivitas adalah: suatu ukuran mengenai apa yang diperoleh dari apa yang dibutuhkan. Perawat memegang peranan utama dalam proses peningkatan Produktivitas karena alat produksi dan teknologi pada hakikatnya merupakan hasil karya manusia. Produktivitas perawat mengandung pengertian perbandingan hasil yang dicapai perawat dengan jangka waktu tertentu.

\section{Dimensi dan Indikator Produktivitas Kerja}

Dimensi dan indikator dalam produktivitas yang diterapkan oleh suatu organisasi tidak selalu sama, tetapi pada dasarnya, dimensi dan indikator yang dinilai itu mencakup beberapa hal, seperti yang dikemukakan oleh Faustino C. Gomes dalam A. Yudapratama (Yudapratama, 2017), yaitu :

1. Keterampilan

Kecakapan yang spesifik yang dimiliki seseorang berkaitan atau berhubungan dengan penyelesaian tugas secara cepat dan tepat. Dimensi keterampilan diukur dengan menggunakan indikator kecakapan dalam penyelesaian tugas. 


\section{Kemampuan}

Kapasitas atau sifat individu yang dibawa sejak lahir atau dipelajari yang memungkinkan seseorang untuk melakukan atau menyelesaikan berbagai macam tugas dan pekerjaan. Dimensi kemampuan diukur dengan menggunakan indikator kapasitas untuk mengerjakan tugas.

3. Sikap dan Perilaku

Keteraturan perasaan dan pikiran seseorang dan kecenderungan bertidak terhadap aspek lingkungannya. Dimensi sikap dan perilaku diukur dengan menggunakan indikator sikap dan perilaku pekerja.

\section{Ciri-Ciri Pegawai Yang Produktif}

Ranftl dalam Timpe (Sembiring, 2016), mengemukakan ciri-ciri pegawai yang produktif sebagai berikut: a). Lebih dari memenuhi kualifikasi pekerjaan: kualifikasi pekerjaan dianggap hal yang mendasar, karena Produktivitas tinggi tidak mungkin tanpa kualifikasi yang benar: $b$ ). Bermotivasi tinggi: motivasi sebagai faktor kritis, pegawai yang bermotivasi berada pada jalan Produktivitas tinggi, c). Mempunyai orientasi pekerjaan positif: sikap seseorang terhadap tugasnya sangat mempengaruhi kinerjanya, faktor positif dikatakan sebagai faktor utama Produktivitas pegawai, d). Dewasa: pegawai yang dewasa memperlihatkan kinerja yang konsisten dan hanya memerlukan pengawasan minimal, e). Dapat bergaul dengan efektif: kemampuan untuk menetapkan hubungan antar pribadi yang positif adalah aset yang sangat meningkatkan Produktivitas.

Sedarmayanti dalam Umar (Sembiring, 2016), mengutip tentang ciri-ciri individu yang produktif dari Erich dan Gilmore, yaitu: a). Tindakan konstruktif, b). Percaya diri, c). Mempunyai rasa tanggung jawab, d). Memiliki rasa cinta terhadap pekerjaannya, e). Mempunyai pandangan kedepan, f). Mampu menyelesaikan persoalan, g). Dapat menyesuaikan diri dengan lingkungan yang berubah, h). Mempunyai konstribusi positif terhadap lingkungan, i). Mempunyai kekuatan untuk mewujudkan potensinya

\section{Faktor-Faktor Yang Mempengaruhi Produktivitas}

Untuk mencapai tingkat produktivitas yang tinggi, suatu perusahaan dalam proses produksi tidak hanya membutuhkan bahan baku dan tenaga kerja saja, tapi juga haarus didukung faktorfaktor lainnya. Adapun faktor-faktor lain yang mempengaruhi produktivitas menurut Siagian dalam Sembiring (Sembiring, 2016) adalah :
a. Pendidikan,
b. Pelatihan,
c. Perjanjian kerja,
d. Penilaian prestasi kerja,
e. Sistem imbalan
f. Motivasi, dan
g. Kepuasan kerja

Dan masih dalam (Sembiring, 2016), untuk mendukung pendapat siagian, Wana Nusa mengungkapkan bahwa faktor-faktor yang mempengaruhi produktivitas kerja yaitu :
a. Pendidikan,
b. Ketrampilan,
c. Disiplin,
d. Motivasi,
e. Sikap dan etika kerja,
f. Gizi dan kesehatan, 
g. Tingkat penghasilan,

h. Jaminan lingkungan dan iklim kerja,

i. Hubungan industrial,

j. Teknologi,

k. Sarana produksi,

1. Manajemen dan kesempatan berprestasi.

\section{METODOLOGI PENELITIAN}

Jenis penelitian yang dilakukan dalam penelitian ini adalah jenis penelitian kualitatif (Sujarweni, 2015) dengan tahapan penelitian adalah tahap persiapan, tahap lapangan dan tahap pengolahan data. Populasi dalam penelitian ini adalah seluruh pegawai termasuk tenaga medis di Pustu Desa Botolakha berjumlah 10 orang sedangkan pengambilan sampel dilakukan secara insidental dengan teknik pengumpulan datanya adalah melakukan pengamatan dan wawancara (Sujarweni, 2015).

\section{HASIL PENELITIAN}

\section{Hasil Pengamatan}

Pengamatan yang dilakukan peneliti di lokasi penelitian juga sangat bermanfaat untuk mendukung kelengkapan data dan informasi agar hasil penelitian yang dilakukan semakin sempurna serta untuk mengetahui fenomena yang terjadi. Maka hasil pengamatan yang diperoleh adalah sebagai berikut:

1. Berdasarkan hasil pengamatan bahwa di Pustu Desa Botolakha Kecamatan Tuhemberua Kabupaten Nias Utara ini memiliki populasi pegawai 10 orang.

2. Penulis mengamati bahwa pelaksanaan kegitan di Pustu Desa Botolakha Kecamatan Tuhemberua Kabupaten Nias Utara telah terstruktur dengan sudah terbentuk susunan struktural, penetapan nama-nama dilakukan oleh pimpinan secara adil dan merata.

3. Penulis mengamati bahwa pimpinan pernah datang langsung kepada pegawai untuk menayakan masalah serta memberikan solusi penyelesaian masalah yang dihadapi.

4. Berdasarkan hasil pengamatan yang telah peneliti lakukan selama meneliti di Pustu Desa Botolakha Kecamatan Tuhemberua Kabupaten Nias Utara telah melakukan beberapa pelatihan kepada pegawai untuk meningkatkan pengetahuan pegawai.

5. Penulis mengamati bahwa setiap pegawai selalu datang dan pulang tepat waktu sesuai dengan jadwal pustu.

6. Berdasarkan pengamatan penulis, pegawai sudah bisa terampil dalam melaksanakan kegiatannya dengan penuh tanggungjawab.

7. Berdasarkan pengamatan penulis masih ada beberapa pegawai yang masih kurang terampil dalam penggunaan alat ilmu pengetahuan dan tekonologi khususnya komputer.

\section{Hasil Wawancara}

Wawancara yang diajukan kepada responden dilakukan berdasarkan daftar pertanyaan yang tersusun. Hasil yang diperoleh dari wawancara tersebut dinarasikan yang disimpulkan oleh penulis berdasarkan jawaban terbanyak dari responden adalah sebagai berikut:

\section{a. Kedisiplinan Pegawai Pustu Desa Botolakha Kecamatan Tuhemberua Kabupaten Nias Utara}

1. Berdasarkan data yang diperoleh dari responden bahwa tujuan dari Dinas telah ditetapkan secara ideal dan benar-benar menantang bagi pegawai, berdasarkan tujuan yang ada maka setiap pekerjaan yang diberikan kepada pegawai sesuai dengan kemampuan pegawai 
sehingga pegawai dapat bekerja dengan penuh tanggungjawab maka kedisiplinan dapat tercapai. Dalam mencapai tujuan yang telah ditetapkan kadang juga menuai kendala, dari hasil wawancara dengan responden menyatakan bahwa masih ada juga pekerjaan yang diberikan tidak terlalu menantang, kadang membuat pegawai menganggap remeh pekerjaan tersebut. Tetapi kenyataan yang ada di lapangan, penulis menemukan bahwa pekerjaan yang telah diberikan dilaksanakan oleh pegawai dengan penuh tanggungjawab sesuai dengan tuntutan tujuan, dan dilaksanakan sesuai dengan kemampuan masingmasing pegawai sekalipun pekerjaan terseut kurang menantang. Pernyataan ini, sejalan dengan pendapat Hasibuan dalam Pratiwi (Pratiwi, 2018) yang mengemukakan indikator-indikator kedisiplinan yang mencakup tujuan dan kemampuan ikut mempengaruhi tingkat kedisiplinan kerja pegawai. Tujuan yang akan dicapai harus jelas ditetapkan secara ideal serta cukup menantang bagi kemampuan pegawai. Hal ini berarti, tujuan dari pekerjaan yang dibebankan kepada seorang pegawai harus sesuai dengan kemampuan pegawai tersebut, agar dia bekerja sungguh-sungguh dan mengerjakannya secara disiplin. Tetapi pekerjaannya jauh dibawah kemampuannya, maka kesungguhan dan kedisiplinan pegawai menjadi rendah.

2. Menurut yang dikemukakan responden dari data yang diperoleh bahwa dalam pelaksanaan tugas yang dikerjakan selama ini sangat dipengaruhi oleh sikap teladan kepemimpinan dari seorang pemimpin yang tercermin dari kebaikan, kejujuran, dan keadilan yang sesuai dengan perbuatannya. Teladan kepemimpinan telah dapat dilaksanakan oleh seorang pemimpin. Hal seperti ini harus dapat dilaksanakan oleh pemimpin agar dapat jadi panutan kepada bawahannya, hal ini telah dapat dicerminkan oleh pemimpin, contohnya berdasarkan unsur dari kedisiplinan misalnya selalu datang dan pulang tepat pada waktunya. Pernyataan ini sesuai dengan pendapat Hasibuan dalam Pratiwi (Pratiwi, 2018) bahwa teladan kepemimpinan sangat berperan dalam menentukan kedisiplinan kerja pegawai. Karena pimpinan dijadikan teladan dan panutan oleh bawahannya. Pimpinan harus memberikan contoh yang baik, jujur, adil serta sesuai dengan perbuatan. Dengan teladan pimpinan yang baik, maka kedisiplinan bawahan pun ikut baik. Tetapi jika teladan pimpinan kurang baik (kurang berdisiplin), maka para bawahan juga akan kurang disiplin.

3. Sebagai seorang pegawai tidak bisa memungkiri bahwasanya setiap orang dalam hal melaksanakan pekerjaanya sudah barang tentu mempunyai tujuan pribadi dalam hal pemenuhan kebutuhan hidup, kebutuhan hidup merupakan hal yang sangat digunakan dalam menjalankan hidup sehingga setiap pegawai mengharapkan upah atau balas jasa dari apa yang telah dilaksanakan, setelah penulis melaksanakan wawancara penulis mendapat suatu data bahwasanya pegawai juga tidak menuntut balas jasa melebihi dari apa yang mereka kerjakan, juga hanya berharap agar balas jasa dapat diberikan sesuai dengan pelaksanaan kerjanya, juga sangat berharap selalu adanya perhatian yang tetap dalam pemenuhan kebutuhan hidup. Hal ini sejalan dengan yang diungkapkan Hasibuan dalam Pratiwi (Pratiwi, 2018), bahwa balas jasa (gaji dan kesejahteraan) ikut mempengaruhi kedisiplinan pegawai, karena balas jasa akan memberikan kepuasan dan kecintaan pegawai semakin baik terhadap pekerjaan, maka kedisiplinan mereka akan semakinbaik pula.

4. Pegawai merasa nyaman dan bekerja dengan sungguh-sungguh ketika keadilan telah terlaksana, tentu keadilan mempunyai pengaruh dalam kedisiplinan pegawai dalam bekerja, keadilan dapat dirasakan oleh setiap pegawai mempunyai hubungan yang sangat erat dari manajemen kepemimpinan seorang pimpinan, setelah penulis melaksanakan wawancara terhadap responden, penulis mendapat informasi yang begitu menarik, bahwa selama ini merasakan bahwa keadilan itu kadang dapat dirasakan dengan baik dan kadang 
juga merasa bahwa telah dianaktirikan, tapi setelah memperhatikan beberapa item wawancara yang disampaikan oleh penulis, dapat disimpulkan hampir seluruh pegawai telah dapat merasa adanya keadilan yang tampak dari kesiapan serta semangat pegawai dalam melaksanakan tugas sangat cepat. Hal ini senada dengan pendapat Hasibuan dalam Pratiwi (Pratiwi, 2018), bahwa keadilan ikut mendorong terwujudnya kedisiplinan kerja pegawai, karena sifat manusia yang selalu merasa bawahannya rendah dan tidak berpengaruh dalam stiap keputusan yang akan dilaksanakan. Hal ini dilakukan karena dia menyadari bahwa dengan keadilan yang baik maka akan menciptakan kedisiplinan yang baik pula. Dirinya penting dan minta diperlakukan sama dengan manusia yang lainnya. Manajer yang cakap dalam kepemimpinannya selalu bersikap adil terhadap seluruh bawahannya.

5. Kepemimpinan seorang atasan yang seringkali memberikan penekanan kepada pegawainya akan memberikan dampak yang sangat signifikan dalam penurunan kinerja seorang pegawai, misalnya dalam hal pengawasan yang diberikan oleh atasan kepada pegawai jangan terlalu berlebihan sehingga pegawai dapat bekerja dengan bebas serta bertanggungjawab, dari apa yang terlaksana di lapangan di Pustu Desa Botolakha Kecamatan Tuhemberua Kabupaten Nias Utara terlihat jelas dengan keadaan pegawai dalam melaksanakan tugasnya secara bebas dan bertanggungjawab penuh sebab seorang atasan tidak melaksanakan pengawasan yang begitu melekat terhadap pegawai. Hal ini senada dengan apa yang dikemukakan Hasibuan dalam Pratiwi (Pratiwi, 2018), bahwa Pengawasan melekat (waskat) adalah tindakan nyata yang paling efektif dalam mewujudkan kedisiplinan pegawai, karena dengan pengawasan ini berarti atasan harus aktif dan langsung mengawasi perilaku, moral, sikap, gairah kerja, dan prestasi bawahannya.

6. Berdasarkan wawancara yang dilakukan terhadap responden adapun sanksi yang diberikan kepada setiap pegawai yang melanggar peraturan dan tata tertib kantor, misalnya pegawai yang sering absen diarahkan oleh atasan dan memberikan sanksi yang sesuai seperti dalam halnya mengurangi tanggungjawab dalam embanan tugas, sehingga pegawai tersebut kurang terampil, apabila pelanggaran yang dilakukan maka atasan melaporkannya ke pihak yang lebih wajib dalam hal tersebut. Kejadian di atas searah dengan pendapat Hasibuan dalam Pratiwi (Pratiwi, 2018), bahwa sanksi hukum memberikan peranan penting dalam memelihara kedisiplinan kerja pegawai. Dengan sanksi hukuman yang semakin berat pegawai akan semakin takut untuk melanggar peraturan-peraturan perusahan, dan sikap perilaku pegawai yang tidak disiplin akan berkurang.

7. Setiap atasan tentunya dalam melaksanakan tugas harus tegas dalam memimpin dan begitu pula dengan bawahan harus dapat loyal kepada atasan, ketegasan yang diterapkan oleh atasan harus sesuai dengan kemanusiaan tanpa menindas seseorang dan merasa dicurangi, ketegasan yang ada di Pustu Desa Botolakha Kecamatan Tuhemberua Kabupaten Nias Utara sudah dapat diterapkan oleh atasan sehingga di kantor tidak ada bawahan yang macam-macam dalam pelanggaran disiplin kantor. Pendapat ini sesuai dengan apa yang dikemukakan oleh Hasibuan dalam Pratiwi (Pratiwi, 2018), bahwa pimpinan harus berani menindak tegas pegawai yang bersikap tidak disiplin sesuai dengan sanksi hukuman yang ditetapkan. Dengan demikian, pimpinan tersebut akan dapat memelihara kedisiplinan pegawai.

8. Setiap pegawai sangat merasa nyaman dikarenakan atasan yang sangat baik dalam menerapkan kedisiplinan, setiap pegawai yang melanggar aturan tidak ditegur didepan orang banyak dan pendisiplinan yang diberi atasan selalu bersifat membangun. Pernyataan ini sejalan dengan pendapat Heidrajchman dalam Ony (Noviantari, 2017) 
bahwa pendisiplinan seharusnya dilakukan dengan memberikan teguran kepada pegawai. Teguran jangan dilakukan di hadapan orang banyak. Karena dapat menyebabkan pegawai yang ditegur akan merasa malu dan tidak menutup kemungkinan menimbulkan rasa dendam yang dapat merugikan organisasi dan selain memberikan teguran dan menunjukkan kesalahan yang dilakukan pegawai, harus disertai dengan saran tentang bagaimana seharusnya berbuat untuk tidak mengulangi lagi kesalahan yang sama.

9. Untuk menjalankan disiplin yang baik, maka seorang atasan selalu segera memberikan pengarahan langsung tanpa harus menundanya, sebab masalah yang ditunda pelaksanaannya sangat berpengaruh dengan kedisiplinan. Pernyataan di atas sesuai dengan pendapat Asmiarsih (Asmiarsih, 2014), Suatu tindakan dilakukan dengan segera setelah terbukti bahwa pegawai telah melakukan kesalahan. Jangan membiarkan masalah menjadi kadaluarsa sehingga terlupakan oleh pegawai yang bersangkutan.

10.Berdasarkan wawancara yang dilakukan penulis terhadap responden, setiap responden masih berharap adanya suatu hasil yang baik dari apa yang telah dilakukan, memperhatikan jawaban responden yang menggambarkan sesuatu pembaharuan telah berlaku untuk meningkatkan Produktivitas kerja pegawai, adanya kualifikasi pekerjaan yang baik dari pegawai dan menganggap sebagai dasar dari produktivitas, bermotivasi tinggi, dan memiliki orientasi pekerjaan. Pendapat di atas sejalan dengan Timpe dalam Fata (Sembiring, 2016). Lebih dari memenuhi kualifikasi pekerjaan, kualifikasi pekerjaan dianggap hal yang mendasar, karena produktivitas tinggi tidak mungkin tanpa kualifikasi yang benar.

\section{b. Produktivitas Kerja Pegawai Pustu Desa Botolakha Kecamatan Tuhemberua Kabupaten Nias Utara}

1. Berdasarkan jawaban responden pada saat wawancara, penulis mendapat data bahwa keadaan latar belakang pendidikan setiap pegawai sudah memenuhi syarat menjadi pegawai handal. Pernyataan ini sesuai dengan pernyataan Siagian dalam (Sembiring, 2016), Tingkat pendidikan, latar belakang pendidikan dan latihan dari tenaga kerja akan mempengaruhi produktivitas, karena perlu diadakan peningkatan pendidikan dan latihan bagi tenaga kerja.

2. Adanya perjanjian kerja kepada pegawai sangat menunjang produktivitas kerja pegawai berdasarkan paparan pegawai kepada penulis saat penulis melaksanakan wawancara. Pernyataan ini sejalan dengan pendapat Siagian (Sembiring, 2016), Perjanjian kerja: merupakan alat yang menjamin hak dan kewajiban pegawai sebaiknya ada unsur-unsur peningkatan produktivitas kerja.

3. Kedewasaan dalam melaksanakan pekerjaan sangat mempengaruhi hasil kerja yang konsisten, dengan demikian jangan terlalu diawasi dengan ketat, kedewasaan ini telah dilaksanakan pegawai sesuai dengan latar pendidikan masing-masing. Pernyataan ini sesuai dengan pendapat Timpe (Sembiring, 2016), pegawai yang dewasa memperlihatkan kinerja yang konsisten dan hanya memerlukan pengawasan minimal.

4. Berdasarkan wawancara terhadap responden, responden dengan mantap menjawab bahwasanya pegawai sudah pada umumnya semua pegawai harus dapat bergaul dengan sesamanya pegawai dalam suatu instansi agar dapat terjalin komunikasi yang baik, berdasarkan wawancara dan pengamatan penulis bahwasanya pegawai sudah memiliki hubungan komunikasi yang baik antar pegawai yang satu dengan yang lain. Pernyataan ini sejalan dengan pendapat Timpe dalam Sembiring (Sembiring, 2016), kemampuan untuk menetapkan hubungan antar pribadi yang positif adalah aset yang sangat meningkatkan produktivitas. 
5. Pegawai harusnya memiliki hasil dari buah kedisiplinan terhadap produktivitas kerja pegawai telah dapat dicerminkan dengan ciri-ciri percaya diri, mempunyai rasa tanggung jawab, memiliki rasa cinta terhadap pekerjaannya,mampu menyelesaikan persoalan. Pernyataan ini sesuai dengan pendapat Umar dalam (Sembiring, 2016) tentang ciri-ciri individu yang produktif dari Erich dan Gilmore, yaitu:
a. Tindakan konstruktif,
b. Percaya diri,
c. Mempunyai rasa tanggung jawab,
d. Memiliki rasa cinta terhadap pekerjaannya,
e. Mempunyai pandangan kedepan,
f. Mampu menyelesaikan persoalan,
g. Dapatmenyesuaikan diri dengan lingkungan yang berubah,
h. Mempunyai konstribusi positif terhadap lingkungan,
i. Mempunyai kekuatan untuk mewujudkan potensinya.

Berdasarkan data yang telah dijelaskan dari atas dan sekaligus membandingkannya dengan landasan teori, maka yang menjadi hasil penelitian berdasarkan tujuan penelitian ini adalah sebagai berikut:

1. Dari hasil pengamatan di lapangan Kedisiplinan di Pustu Desa Botolakha Kabupaten Nias Utara terlaksana dengan baik.

2. Pegawai sudah memiliki hubungan komunikasi yang baik antar pegawai yang satu dengan yang lain di Pustu Desa Botolakha Kabupaten Nias Utara.

3. Peranan kedisiplinan terhadap produktivitas kerja pegawai di Pustu Desa Botolakha Kabupaten Nias Utara memiliki keterikatan yang tidak dapat dipisahkan dengan baik.

4. Produktivitas kerja pegawai di Pustu Desa Botolakha Kabupaten Nias Utara terlaksana dengan baik.

5. Berdasarkan hasil wawancara yang telah dinarasikan bahwa kedisiplinan di Pustu Desa Botolakha Kabupaten Nias Utara terlaksana dengan baik.

6. Berdasarkan hasil wawancara yang telah dinarasikan bahwa produktivitas kerja pegawai di Pustu Desa Botolakha Kabupaten Nias Utara mencirikan pegawai yang produktivitas.

\section{KESIMPULAN \& SARAN}

Dari hasil penelitian yang telah dilakukan maka dapat disimpulkan bahwa kedisiplinan pegawai di Pustu Desa Botolakha Kecamatan Tuhemberua Kabupaten Nias Utara telah terlaksana dengan baik dan kedisiplinan tersebut memiliki peranan yang sangat penting dalam meningkatkan produktivitas kerja para pegawai Pustu Desa Botolakha Kecamatan Tuhemberua Kabupaten Nias Utara. Dan yang menjadi saran dalam penelitian ini hendaknya kedisiplinan ditingkatkan lagi dan sebaiknya bentuk tanggung jawab yang diberikan selalu disesuaikan dengan kemampuan masingmasing pegawai.

\section{BIBLIOGRAPHY}

Asmiarsih. (2014, Februari). e-jurnal. Dipetik Januari 8, 2020, dari Jenis-Jenis Disiplin Kerja: https://www.e-jurnal.com/2014/02/jenis-jenis-disiplin-kerja.html

Bugis, S. (2018). HUBUNGAN ANTARA KOMITMEN ORGANISASI DENGAN DISIPLIN KERJA PADA ANGGOTA LEMBAGA DAKWAH KAMPUS (LDK) DI YOGYAKARTA. Dipetik Januari 8, 2020, dari eprints.mercubuana-yogya: http://eprints.mercubuana-yogya.ac.id/id/eprint/3789 
Diah Indriani Suwondo, E. M. (2015). Hubungan Lingkungan Kerja, Disiplin Kerja, dan Kinerja

Karyawan. Jurnal Manajemen dan Kewirausahaan, 17.

Harahap, R. E. (2016). HUBUNGAN KEPEMIMPINAN TRANSFORMASIONAL DAN DISIPLIN KERJA DENGAN KINERJA PERAWAT RUMAH SAKIT TK.II PUTRI HIJAU MEDAN. Jurnal MAgister Psikologi UMA, 8.

Hendra Praja, G. a. (2017). ANALISIS DAMPAK PRODUKTIVITAS KERJA TERHADAP KESEJAHTERAAN KARYAWAN USAHA AYAM BROILER DALAM PERSPEKTIF EKONOMI ISLAM. Skripsi thesis, UNIVERSITAS ALMA ATA YOGYAKARTA. Dipetik Januari 9, 2020, dari elibrary.almaata: http://elibrary.almaata.ac.id/776/1/NASKAH\%20PUBLIKASI\%20GUSTARA.pdf

Mauliya Siti Aisyah, T. A. (2019, Oktober 2). Analisis Disiplin Kerja Pada Sales Promotion Girl (SPG) dan Sales Promotion Boy (Studi KAsus Pada MDS PAragon Semarang). Jurnal Solusi .

Noviantari, O. (2017). Disipin Pegawai dalam Meningkatkan Kualitas Pelayanan Publik di Kantor Camat Siantar Kabupaten Simalungun. Dipetik Januari 9, 2020, dari repositori.usu: http://repositori.usu.ac.id/handle/123456789/3201

Pratiwi, M. (2018). Pengaruh Kedisiplinan dan Motivasi Kerja Terhadap Kinerja KAryawan PAda STIH Sumpah Pemuda Palembang. Dipetik Januari 8, 2020, dari eprints.polsri: http://eprints.polsri.ac.id/5991/3/BAB\%20II.pdf

Sembiring, T. (2016). Pengaruh Lingkungan Kerja Terhadap Produktivitas Kerja Pegawai Pada Direktorat Keuangan RSUP H. Adm Malik Medan. Dipetik Januari 9, 2020, dari repository.uma: http://repository.uma.ac.id/handle/123456789/881

Silalahi, S. P. (2017). Pengaruh Kedisiplinan Kerja dalam Meningkatkan Produktivitas Kerja Karyawan pada PT. Perkebunan Nusantara IV Kebun Tobasari. Jurnal Ilmiah Methonomi , 3, 14-21.

Sujarweni, V. W. (2015). Metodologi Penelitian Bisnis \& Ekonomi.

Sulfemi, W. (2018). Pengaruh disiplin Ibadah Sholat, lingkungan sekolah,dan intelegensi Terhadap Hasil Belajar Peserta Didik Mata Pelajaran Pendidikan Agama Islam. Jurnal Penelitian Pendidikan Agama dan Keagamaan , 16, 166-178.

Trihudiyatmanto, M. (2017). Pengaruh Motivasi Dan Kedisiplinan Kerja Terhadap Produktivitas Karyawan. Jurnal Penelitian Dan Pengabdian Kepada Masyarakat UNSIQ 4 (1) Tahun 2017 1, 20 , 1, 20.

Yudapratama, A. (2017). Pengaruh Disiplin dan Kompensasi Terhadap Produktivitas Karyawan UKM Pada Sentra Sepatu Cibaduyut di Bandung. Dipetik Januari 9, 2020, dari repository.unpas: http://repository.unpas.ac.id/id/eprint/32794 